\title{
Improving Vocabulary Using a Computer-based Flashcard Program
}

\author{
Hasbullah $^{* 1}$, Sanitah Bte Mohd Yusof ${ }^{2}$, Muhammad Yaumi ${ }^{3}$, Adamu Mallam \\ Babikkoi $^{4}$ \\ ${ }^{*}$ Sekolah Tinggi Agama Islam Negeri (STAIN) Sorong, Papua Barat, Indonesia \\ email: hasbullahsaid68@gmail.com \\ ${ }^{2}$ Faculty of Education, Universiti Teknologi Malaysia, Johor Bahru, Malaysia \\ ${ }^{3}$ Universitas Islam Negeri Alauddin, Makassar, Indonesia \\ ${ }^{4}$ School of Languages, Federal College of Education, Yola, Adamawa State, Nigeria
}

\begin{abstract}
Numerous complications in conveying students'ideas and comprehending the words from teachers due to lack of academic vocabulary Many teaching techniques or strategies the teacher can use to make students learn the vocabulary effectively. This study aims at examining the effectiveness of Computerbased Flashcard Program (CFP) is effective in teaching vocabulary. Pre-experimental method with one group pretest and posttest was the design of this study. This study involved thirty one students of Islamic Junior High School in Makassar city, Indonesia chosen conveniently. The data were collected through a vocabulary test to examine the effectiveness of CFP to improve the vocabulary mastery using t-test. The result of the data analysis showed that there was a significant difference between pretest and posttest. This study found that use of CFP is effective to improve vocabulary mastery.
\end{abstract}

\section{Keywords -Vocabulary mastery; vocabulary test; Computer-based Flashcard}

\section{INTRODUCTION}

In the current era, mastering English can help many people communicating with other people around the world. Lack of English mastery in English as a Foreign Language (EFL) country is crucial to deal with in the globalization era. From the beginning until now, English has been used as an international language for official international communication in global business. English is also world-widely used as programming languages, books, and journals. In addition, the era of ASEAN Economic Community and Free Trade Zone among countries requires people around the world afford to have the ability to speak English [1]-[4]. In learning English, a fundamental element to consider is the vocabulary. Vocabulary as one of the language elements has important role in communication either in spoken or written form. All words of a language are termed as vocabulary to achieve language skills (listening, speaking, reading, and writing). Vocabulary mastery are required when people want to listen, speak, read, and write to understand the meaning, the diction, sentence structure or the pronunciation of the words [5]-[8]. Thus, vocabulary is a fundamental element in language skills.

Mastering a language requires reflective understanding the vocabulary [5]. Speaking in English, for example, students find difficulty in speaking English with lack of English vocabulary. Students cannot understand well when they listen to the teachers' instruction. Students also find difficulty in accomplishing task when they are reading the instruction of the assignment and write the 
answer in the worksheet [7]. In other words, vocabulary is a very vital component of language learning. Without understanding vocabulary, students cannot understand the idea on listening and reading and find difficulty in expressing ideas in speaking and writing. Some previous studies found that many difficulties in expressing students'ideas and understanding the words from teachers because of lack of academic vocabulary [9]. To overcome the problem, teachers should emphasize the vocabulary elements in their teaching materials and learning strategy. Teachers can assign the students to make an effort in increasing the vocabulary. There are many teaching techniques or strategies that the teacher can use. Student's vocabulary mastery improved after they were taught by using flashcard and wordlist [10]-[15].

A few students in Dubai began using a piece of free software with the aim of helping students recalling the target vocabulary. The software with a flipped to vocabulary teaching used spaced repetition for consolidation [11]. However, the method focused on delivering the basic teaching of the vocabulary items and lack of vocabulary learning. Integrating a CFP into vocabulary learning revealed that the process of learning academic vocabulary helped students to improve their academic vocabulary [10], [15]. However, the study focused on the English as Second Language (ESL) college student. Whereas, the target of the participant in this study were the English as Foreign Language (EFL) students. Moreover, the different level of college and junior high school students also determines the level of vocabulary mastery [16]. This study focused on helping young learners to improve vocabulary mastery.

Some previous studies found the use computer-assisted language learning with spaced repetition as the platform of CFP. Spaced repetition can help the users to create their own course books using application such us: Supermemo, Anki, Mnemosyne, and Fullrecall [11], [12], [17]-[19]. The study focused on helping students to create course books. However, some other studies reported the research on how to teach students' vocabulary by using word list to make teaching and learning process more effective and interesting, especially in teaching English. Student's vocabulary mastery improved after they were taught by using flashcard and wordlist conducted research [10]. Word list can guide both English teacher and student attention and efforts for both comprehension and production of English vocabulary [20]. Giving student only 10 minutes of vocabulary instruction enhanced student's motivation to study and led them to spend more time on vocabulary made $70 \%$ of the students increased their vocabulary test scores [21]. The previous findings above revealed valuable information about the students' ability in studying English. Particularly, the studies were approximately the improvement of English vocabulary using different media and method of teaching. The researchers in this study used CFP to improve the vocabulary of Junior High School students.

\section{MATERIALS AND METHOD}

\section{A. Materials}

The materials on the treatment were based on topic provided in the running English textbook for Islamic Junior High School at Makassar for the third year students. The researchers used Computer-based Flashcard Program (CFP) as

International Journal on Advanced Science, Education, and Religion (IJoASER) 
media to improve students' vocabulary mastery. CFP is a program designed to afford a communicating flash card experience by logically arranging cards. CFP steadily presents new cards and provides an effective way to study without affecting information excess. The researchers used vocabulary achievement test to measure the students' vocabulary mastery using CFP in teaching and learning process. The researchers used the vocabulary test in pretest and posttest to find out the effectiveness of CFP teaching and learning on the improvement of students' vocabulary. The researchers used fifteen multiple-choice items, fife filling the blank items, six matching items, four spelling the words items, and five making sentences items. Thus, thirty five items total were assigned to students to answer the test in sixty minutes.

\section{B. Method}

Thirty one students of Islamic junior high school involved in this study in academic year 2017/2018. The researchers used convenient sampling due to this study was conducted as extracurricular activity. Only those who were convenient to be included in the study were tested. The researcher conducted the research in seven meetings. In the first meeting, the researchers provided pretest. The researcher conducted teaching and learning using CFP as treatments in five meetings. After conducting treatment for five meetings, the researchers gave the posttest. The procedure and the materials in posttest were the same as in the pretest. The results of pretest and posttest were calculated to measure the students' vocabulary mastery using CFP.

\section{RESULTS}

\section{A. The percentage of Students' Vocabulary Mastery}

This Figure 1 describes the students' score on pre-test and post-test. The pretest results was coded in orange and post-test in blue colour. The following Figure 1 indicates the percentage of vocabulary mastery after treatment on CFP use. The score is ranging from college-level-work to excellent to good [22]. The details of the vocabulary mastery percentage in this study is shown in Figure 1 below.

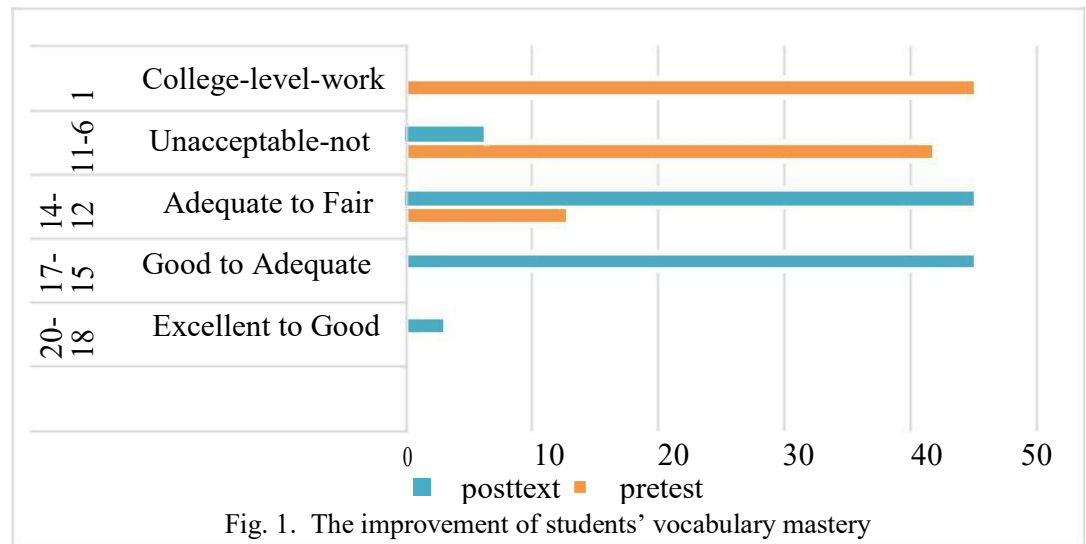

IJoASER, Volume 1, Issue 1, March 2018 
Figure 1 above indicates the percentage of students' vocabulary mastery after teaching and learning using CFP media. The majority of the students were in collegelevel-work and unacceptable-not in the pre-test, they were forty five and forty two percent respectively. Remarkably, there was no any students were in the college-levelwork and remained only six percent students were in unacceptable-not in post-test. Thirteen percent students who were in adequate to fair in pre-test increased considerably to be forty five percent in post-test. Remarkably, there was no any students who were in excellent to good in pre-test, but increased to be three percent in the post-test.

\section{B. The Mean Score and Standard Deviation of the Students' Vocabulary Mastery}

Calculating the mean score and standard deviation in pre-test and post-test was used to investigate the improvement of using CFP in teaching and learning vocabulary. Table 1 below indicated that the mean score increased from 51.1 to 73.6 and the standard deviation declined from 11.2 in pre-test to 10.4 in post-test. The details of the mean score and standard deviation in this study is shown in Table 1 below.

TABLE 1

THE MEAN SCORE AND STANDARD DEVIATION OF THE STUDENTS' VOCABULARY MASTERY

Mean Score Standard Deviation

Pre-test

51.1

11.2

Post-test

73.6

10.4

Table 1 above indicates the improvement of students' vocabulary mastery from 51.1 of mean score in pre-test to 73.6 in post-test. The declined of the standard deviation from 11.2 in pre-test to 10.4 in post-test indicates the score of 10.4 is closer to mean score 73.6. The decrease of the standard deviation also as an indication that the data points are close to the expected value [23]. Undoubtedly, by using CFP media, vocabulary mastery of the students increased significantly.

\section{DISCUSSION}

The significance difference between the pre-test and post-test using CFP in vocabulary teaching and learning indicates an effectiveness to improve the students' vocabulary mastery. The description of the data collected through vocabulary test as presented in percentage chart (see Figure 1) showed the improvement of the students' vocabulary mastery. It was supported by the mean score and standard deviation of the students in pre-test and post-test (see Table 1). 
In pre-test, the researcher provided the students vocabulary test. The students were given sixty minutes to answer the test. Pre-test was intended to investigate the prior level of students' vocabulary mastery. The post-test was intended to find out the improvement of students' vocabulary mastery after treatments. In the process of the pretest, generally the students looked confused, because they didn't know what they should answer and they couldn't develop their ability in English because they had less vocabulary. In addition when the pretest was given, the students just crossed their answers without thinking more whether their answers were the right answer or not. In the pre-test, there were thirteen percent of students categorized into adequate to fair, forty two percent were in unacceptable-not, and forty five percent categorized into college-level-work.

Based on the pre-test result, the researchers provided the treatments for students by using CFP. The treatment carried out for five meetings of teaching-learning process. Each meeting spent about ninety minutes. The procedure of the treatments was same from the first to the fifth meeting. However, the materials was different in every meeting, these topics were taken from English for the third year of Islamic Junior High School Makassar. During the treatment, the researchers assigned the students to review the words at home.

The students seemed to be interested in the CFP media of teaching and learning because they can use it in their laptops without difficulty [15]. Students can find new words, make and share their level. In addition, students also felt enjoy during the learning process. After offering treatment for five meetings, the researchers offered post-test to be acquainted with the improvement of the students' vocabulary mastery after the students taught by using CFP. Relating the data provided in Figure 1 and Table 1, the researchers affirmed that using CFP in vocabulary learning in five meetings improved the students' vocabulary mastery.

\section{CONCLUSIONS}

Based on the percentage and mean score as well as standard deviation from pre-test to post-test, this study showed that students' vocabulary score using CFP increased. The increased score also indicated the improvement of students' vocabulary mastery using CFP. This study also revealed that by using CFP media, students seemed to be interested in studying English vocabulary. It can be concluded that the use of CFP was effective to improve vocabulary mastery of junior high school students.

In teaching and learning English, using a CFP is highly recommended for the teacher of English to improve students' vocabulary mastery. Teacher can choose any topic as the materials for teaching and learning. The CFP media was supposed to be beneficial both for teacher and students to run the learning method effectively and to make students more interested in learning English. The teacher can assign the students to use CFP to discover new words and make their own level.

The teacher should establish a good relation with all the students in class

IJoASER, Volume 1, Issue 1, March 2018

DOI :10.33648/ijoaser.v1i1.4

Copyright: STAI Al-Furqan Makassar,Indonesia

Content License: CC-BY-SA 
firmly to create a good atmosphere in learning and reinforce them with a good motivation to be successful in teaching and learning English vocabulary. Indeed, many other approaches, strategies, or method for teachers to challenge the students learning vocabulary. However, the CFP exposed noteworthy improvement on the students' vocabulary mastery.

\section{REFERENCES}

[1] R. W. Cox, The new realism: Perspectives on multilateralism and world order. Springer, 2016.

[2] C. R. Severino, Southeast Asia in search of an ASEAN community: Insights from the former ASEAN secretary-general. Institute of Southeast Asian Studies, 2006.

[3] J. Kurlantzick, "ASEAN's future and Asian integration," Counc. Foreign Relations, vol. 20, 2012.

[4] S. Castles, H. De Haas, and M. J. Miller, The age of migration: International population movements in the modern world. Palgrave Macmillan, 2013.

[5] R. Carter and M. McCarthy, Vocabulary and language teaching. Routledge, 2014.

[6] B. Y. Cahyono and U. Widiati, "The teaching of EFL vocabulary in the Indonesian context: the state of the art," TEFLIN J., vol. 19, no. 1, pp. 1-17, 2015.

[7] M. F. Graves, The vocabulary book: Learning and instruction. Teachers College Press, 2016.

[8] J. C. Richards and T. S. Rodgers, Approaches and methods in language teaching. Cambridge university press, 2014.

[9] D. Gardner, "Academic Vocabulary List," TESOL Encycl. English Lang. Teach., 2018.

[10] E. Y. Sitompul, "Teaching Vocabulary Using Flashcards and Word List," J. English Educ., vol. 1, no. 1, pp. 52-58, 2013.

[11] N. Fallows and N. Fallows, "A Flipped Approach to Vocabulary Teaching in HCT Dubai Colleges Foundations Level 03: Utilising Spaced Repetition for Consolidation," UAE J. Educ. Technol. ELearning, vol. 4, pp. 35-39, 2013.

[12] X.-L. Pham, G.-D. Chen, T.-H. Nguyen, and W.-Y. Hwang, "Card-based design combined with spaced repetition: A new interface for displaying learning elements and improving active recall," Comput. Educ., vol. 98, pp. 142-156, 2016.

[13] K. P. Miles and L. C. Ehri, "Learning to Read Words on Flashcards: Effects of Sentence Contexts and Word Class in Native and Nonnative English-Speaking Kindergartners," Early Child. Res. Q., vol. 41, pp. 103-113, 2017.

[14] S.-A. A. January, M. E. Lovelace, T. E. Foster, and S. P. Ardoin, "A comparison of two flashcard interventions for teaching sight words to early readers," J. Behav. Educ., vol. 26, no. 2, pp. 151-168, 2017.

[15] C.-W. Chien, "Analysis the Effectiveness of Three Online Vocabulary Flashcard Websites on L2 Learners' Level of Lexical Knowledge.," English Lang. Teach., vol. 8, no. 5, pp. 111-121, 2015.

[16] A. Pinter, Teaching young language learners. Oxford University Press, 2017.

[17] E. Chukharev-Hudilainen and T. A. Klepikova, "The effectiveness of computer-based spaced repetition in foreign language vocabulary instruction: a double-blind study," calico J., vol. 33, no. 3, 2016.

[18] J. V. Bower and A. Rutson-Griffiths, "The relationship between the use of spaced repetition software with a TOEIC word list and TOEIC score gains," Comput. Assist. Lang. Learn., vol. 29, no. 7, pp. 1238-1248, 2016.

[19] D. Keder, "Computer-assisted language learning using spaced repetition.” Masarykova univerzita, Fakulta informatiky, 2009.

[20] M. Lessard-Clouston, "Word Lists for vocabulary learning and teaching.," CATESOL J., vol. 24 , no. 1 , pp. $287-304,2013$.

[21] N. Takahashi, "The Effects of 10-minute vocabulary instruction: Using word lists in the EFL classroom," Retrieved Novemb., vol. 20, no. 2015, pp. 37-50, 2011.

[22] H. D. Brown and P. Abeywickrama, Language assessment: principles and classroom practices. Pearson Education, 2010.

[23] P. R. Hinton, I. McMurray, and C. Brownlow, SPSS explained. Routledge, 2014. 